\title{
The Relationships between Foreign Exchange Volatility Skew and Jump Risk
}

\author{
Chia Rui Ming Daryl ${ }^{1}$ \\ ${ }^{1}$ Department of Statistics, University of Warwick, Coventry, United Kingdom \\ Correspondence: Chia Rui Ming Daryl, Department of Statistics, University of Warwick, Coventry, CV4 7ES, \\ United Kingdom. Tel: 44-7928-065-816. E-mail: r.m.d.chia@warwick.ac.uk
}

Received: March 31, 2014

Accepted: April 16, 2014

Online Published: May 25, 2014

doi:10.5539/ijef.v6n6p70

URL: http://dx.doi.org/10.5539/ijef.v6n6p70

\begin{abstract}
In this novel study, I investigate whether option implied volatility and implied volatility skew contain information capable of elucidating, in an ex-ante manner, the probability of exceptional foreign exchange price fluctuations. I study four of the most widely traded currency pairs and their corresponding options over varying option maturities and distinct definitions of volatility skew and price jumps, each over the period 1 Jan 2007 to 18 November 2013. I find significant evidence of such informational content in at-the-money implied volatility, implied volatility skew and currency forward premium, each with differing degrees of influence. Further, as opposed to results in existing literature on price jumps within the equity asset class, the ability of volatility skew to predict price jumps does not attenuate with an increasing option maturity up to three months. I also observe through probit marginal analysis how at-the-money implied volatility dominates in its influence of price jump probability, while currency carry and implied volatility skew hold smaller but nonetheless significant influence.
\end{abstract}

Keywords: volatility skew, price jumps, foreign exchange options

\section{Introduction and Literature Review}

Despite the high degree of integration between the markets for options and their underlying, it is widely documented how option implied volatility and implied volatility skew contain information capable of elucidating, in an ex-ante manner, future security returns and the probability cum magnitude of forthcoming jumps in security prices.

The theoretical framework underlying such a phenomenon finds its roots in the jump-diffusion model of asset-pricing pioneered by Merton (1976). Within such a framework, the return series of a security is an amalgamation of diffusive risk modelled as Brownian motion and jump risk that follows a Poisson process. Therein, the average jump in a stock's price determines its returns, and the size of such jumps may be deduced from the slope of the asset's implied volatility skew. Such provides theoretical support to the said predictive power of implied volatility skew, and the jump-diffusion model itself finds strong support from a vast body of empirical work that goes beyond the classic diffusion model of Black and Scholes (1973) to prove the importance of including jumps in a diffusion model of asset pricing. These studies include Ball and Torous (1985), Naik and Lee (1990), Bakshi, Cao and Chen (1997), Eraker, Johannes and Polson (2003) and in particular Bates (2000), which succinctly shows that in a post-' 87 world of persistent negative skew in S\&P 500 implied volatility, the use of a stochastic volatility asset-pricing model would require unrealistic parameters if it were not to incorporate a jump-diffusion model that significantly enhances its fit vis-à-vis observed option prices. That said, drawing from theoretical work to answer why implied volatility and implied volatility skew are able to predict asset returns and price jumps is beyond the scope of this paper. Instead, I focus on contributing to the literature through an empirical search for the presence of such effects within the sphere of foreign exchange, where literature on the predictive power of implied volatility and implied volatility skew is scarce. However, before I move into unchartered territory, a review of the empirical work on volatility within the well-documented field of equities is due.

First, I acknowledge findings that-abstracting from skew-levels of implied volatility do in fact contain predictive power for stock returns. Giot (2005) demonstrated such by means of examining the return profile of the S\&P 500 and NASDAQ 100 indices at distinct levels of the CBOE VIX and VXN during 1994 to 2003. It was concluded that the volatility indices were effective as overbought/oversold indicators and that high levels of 
implied volatility-especially occurring amid low volatility regimes-is typically followed by attractive positive returns. Later on, Banerjee, Doran and Peterson (2007) proved that over 1986 to 2005, VIX levels-but not innovations-were significant in predicting S\&P 500 returns on a 30- and 60-day forward looking basis, and that such a result was robust to adjusting returns for Carhart (1997) factor exposures, that being the three Fama and French (1993) factors and the momentum factor from Jegadeesh and Titman (1993). Such results were corroborated at higher granularity by Ammann, Verhofen and Suss (2009) based on OptionMetrics individual-options' data over the 1996 to 2005 period, and is also congruent with earlier theoretical work by Pan (2002), which shows that the jump risk premium in the jump-diffusion model is highly correlated with implied volatility. Alas, present literature points unequivocally toward a significant relationship between implied volatility and future returns cum jump risk-however, abstracting from the level of volatility, can one say the same regarding the implied volatility skew?

The literature on implied volatility skew and its predictive power for asset returns and jump risk, albeit slightly more scarce, comes to a similar conclusion, that there is information in implied volatility skew for predicting returns, jump probability and jump intensity. In proving the effectiveness of volatility skew measures in predicting returns, Yan (2011) ranked 4,048 stocks according to the slope of their implied volatility smile as measured by the local steepness of at-the-money near-expiration options over 1996 to 2005 and found the difference in average annual return of the top and bottom quintile amounted to a staggering $22.2 \%$. Equally important, such profitability was robust to the level of implied volatility, the Carhart (1997) risk factors and to historical skewness. Further, Yan (2011) found that the strategy's profitability was mainly attributed to profits in the first of a six month holding period, implying that the predictive power of volatility skew was primarily or exclusively in short-term options. Such result is consistent with longstanding empirical findings on how the predictive power of implied volatility skew attenuates significantly beyond a one-month horizon. Later on, Doran and Krieger (2010) corroborates such findings by demonstrating that higher returns are positively related to higher negative skew as measured by the left side of the implied volatility skew, namely the difference between OTM and ATM put option implied volatilities.

Finally, of most significance to this study, Doran, Peterson and Tarrant (2007) demonstrated with the use of probit regressions that volatility skew contributed significantly to the likelihood of S\&P 100 'market crashes' in a 10 to 30 day forward looking time horizon, and that such predictive ability was absent in the 31 to 60 and 61 to 90 day maturity buckets. Such results were robust to the definition of skewnewss - the authors found similar results applying both multiple skew measures to represent distinct sections of the implied volatility skew and a summary risk-neutral measure of skewness derived in Bakshi, Kapadia and Madan (2003). Also, the results were robust to the definition of a 'market crash', of which two definitions were used - the sample top $5 \%$ and $1 \%$ of daily percentage moves and the sample top $5 \%$ and $1 \%$ of daily percentage moves normalised by localised volatility within a backward looking window of lengths of 16 and 30 days, as espoused by Lee and Mykland (2006). The authors' results were also controlled for ATM implied volatility, percentage bid-ask spread of OTM puts, open interest of OTM puts, volume traded of OTM puts, the term structure of interest rates (measured as the spread between 10 year and 1 year U.S. Treasury notes) and the term structure of volatility (measured as the difference between the average implied volatility of 10 to 30 day maturity ATM calls and 31 to 60 or 61 to 90 day ATM calls).

With the empirical literature covering the equity space laid out, I may begin to focus on the objectives of this paper. In this paper, I aim to contribute to existing literature by performing similar empirical investigations on foreign exchange spot rates of the most widely traded currencies. My primary goal is to determine if the degree of implied volatility skew across currencies are a significant predictor of price jumps, as they have been shown to be in the equity markets. Such a study within the foreign exchange asset class is entirely novel - present literature on foreign exchange implied volatility and return prediction have focused on levels of implied volatility rather than skew, and examples of such are Lustig, Roussanov and Verdelhan (2011), Della Corte, Ramadorai and Sarno (2013) and Menkhoff et al. (2012). I see this novel study as both justified and long overdue given the spread of literature that appropriately models exchange rate movements within a jump-diffusion framework, such as Jorion (1989), Ball and Roma (1993), Bates (1996), Doffou and Hilliard (2001), Maheu and McCurdy (2007), Song (2011) and Bo, Wang and Yang (2010). In performing the empirical tests, I will be alert to any parallels I can draw with results from the equities space. In particular, I will observe whether the predictive power of skew attenuates with time horizon and if the said predictive power is robust to definitions of price jumps and of skew, and also to currency carry. Towards that end, I employ the use of a probit model akin to Doran, Peterson and Tarrant (2007) and adopt definitions of skew from Doran, Peterson and Tarrant (2007), Doran and Kevin (2010) and Mixon (2011). Further, I suggest and implement an improvement on 
the Lee and Mykland (2006) methodology of normalising returns with fixed-window localised volatility by instead using the Bollerslev (1986) GARCH(1,1) conditional variance as the normalising factor. Such is in view that the Lee and Mykland (2006) methodology risks insufficiently discounting volatility innovations at the back-end of its look-back window, is highly sensitive to the arbitrary choice of the number of look-back days and that, on the other hand, $\operatorname{GARCH}(1,1)$ volatility pays due consideration to heteroskedasticity present in exchange rate time series. Finally, an important caveat is in order — one would intuitively expect high interest rate 'carry' currencies to trade with equity-like characteristics given its high loading to the 'slope' factor and equity market volatility as espoused in Lustig, Roussanov and Verdelhan (2011). Such currencies and their corresponding implied volatility skew may hence be merely serving as a proxy for global equity markets. Given this, I am also interested in examining whether the predictive power of volatility skew is robust to currency carry. Towards that end, I employ a different approach typical of academic literature and of which is espoused in Menkhoff et al. (2012) - that being the segregation of a broad cross-section of currencies into low and high carry groups based on forward spread to spot. Instead, I recognise that currency carry differs not merely between currencies but also across time for a given currency, and I hence exploit such time variation by including carry as a factor in my probit regressions.

\section{Data and Methodology}

With the U.S. Dollar (USD) serving as quote currency, spot rate and option market data for the Euro (EUR), Pound Sterling (GBP), Australian Dollar (AUD) and Japanese Yen (JPY) were extracted from the Bloomberg Professional service for the period 1 Jan 2007 to 18 November 2013. While currency spot rates and option implied volatility data were available for all G10 currencies and a range of emerging market currencies, I choose to limit the study to the abovementioned currencies for the sake of brevity - these currencies make up the majority of global trading volume (58\%, according to the Bank of International Settlements April 2013 Triennial Central Bank Survey), and given that I will be performing 60 probit regressions per currency (a combination of 3 time horizons, 5 skew definitions, 2 definition of jumps and 2 directions of jumps), I choose to focus the analysis on only the most-frequently traded currencies. Further, such a period of study was chosen not only due to reasons of options market data availability, but also to reflect the crisis and post-crisis trading regimes of which include a wide range of variability in currency carry and implied volatilities, both of which I will exploit in the regressions. Specifically, the following data was extracted, all of which are of daily frequency and correspond to the closing mid-price of the New York trading day:

i. Currency spot rates (price of a currency in terms of USD);

ii. 1-month forward premiums (forward price minus spot price);

iii. Implied volatilities of at-the-money (ATM) options;

iv. Implied volatilities of 25-delta calls and 25-delta puts;

v. Implied volatilities of 10-delta calls and 10-delta puts;

vi. 2-week $\operatorname{GARCH}(1,1)$ conditional volatilities estimated via MLE by Bloomberg.

In points 3 to 6 above, I extract each dataset for three option maturity horizons - 2-week, 1-month and 3-months. Note that Bloomberg Professional does not directly provide implied volatility data - instead, butterflies (BF) and risk reversals (RR) are provided, and these are converted deterministically to implied volatilities by solving simultaneous equations (1) and (2) below, where the call and put implied volatilities (IV) are those of either the 25-delta or 10-delta options, depending on the circumstance.

$$
\begin{aligned}
& B F=\frac{\left(I V_{\text {call }}+I V_{\text {put }}\right)}{2}-I V_{A T M} \\
& R R=I V_{\text {call }}-I V_{\text {put }}
\end{aligned}
$$

With the required data at hand, daily spot exchange rates are converted to percentage day-on-day changes. This series of daily price changes is then converted to a series of binary variables which take a value of 1 on any given day if a downward 'price jump' occurred and 0 otherwise. A downward price jump is defined initially as the largest percentage daily price change within the bottom $5 \%$ of negative daily price changes. Further to this, another series of binary variables is generated for upward price jumps, where upward price jumps are defined as the smallest percentage daily price change within the top $5 \%$ of positive daily price changes. Then, two further binary variable series are generated to represent the occurrence of 'scaled price jumps', of which are defined as the largest (smallest) percentage price change within the bottom (top) $5 \%$ of negative (positive) daily price changes scaled by-i.e., divided by-the 2 -week $\operatorname{GARCH}(1,1)$ conditional volatility on each corresponding day. 
The abovementioned price jump corresponds to that in Doran, Peterson and Tarrant (2007) while the normalised price jump definition is a novel adaptation of Lee and Mykland (2006) and Doran, Peterson and Tarrant (2007). Alas, for each of the four abovementioned series of binary variables, indicator functions are generated for each time horizon $s$ that takes a value of 1 on day $t$ if a price jump occurred between day $t$ and $(t+s)$. In this study, $s$ represents the 2-week, 1-month and 3-month option maturity time horizons. Before moving on, note that because the $s$ period indicator functions looks $s$ periods forward in determining its value, there are effectively only $(n-s)$ data points of such a binary variable where $n$ is the total number of data points in the sample. To ensure that results from regressions of different $s$ values are comparable, I limit the binary variable series corresponding to 2-week and 1-month maturities to only the first (n-s) periods for $s$ representing the number of trading days in a 3-month maturity period.

Next, skew measures are calculated. I adopt definitions of skew from Doran, Peterson and Tarrant (2007), Doran and Kevin (2010) and Mixon (2011) — there are 5 definitions each of left and right skew:

$$
\begin{gathered}
\text { SKEW_L1 }=10 D P-25 D P \\
\text { SKEW_L2 }=10 D P-A T M \\
\text { SKEW_L3 }=10 D P-25 D C \\
\text { SKEW_L4 }=25 D P-25 D C \\
\text { SKEW_L5 }=(25 D P-25 D C) / A T M \\
\text { SKEW_R1 }=10 D C-25 D C \\
\text { SKEW_R2 }=10 D C-A T M \\
\text { SKEW_R3 }=10 D C-25 D P \\
\text { SKEW_R4 }=25 D C-25 D P \\
\text { SKEW_R5 }=(25 D P-25 D C) / A T M
\end{gathered}
$$

Taking an example to illustrate the notation, equation (3) indicates that the first definition of left skew is given by the 10-delta put IV less the 25-delta put IV. The first 4 skew measures are illustrated in Figure 1- the figure should make interpretation of the fifth measure and the corresponding right skew measures obvious as well.
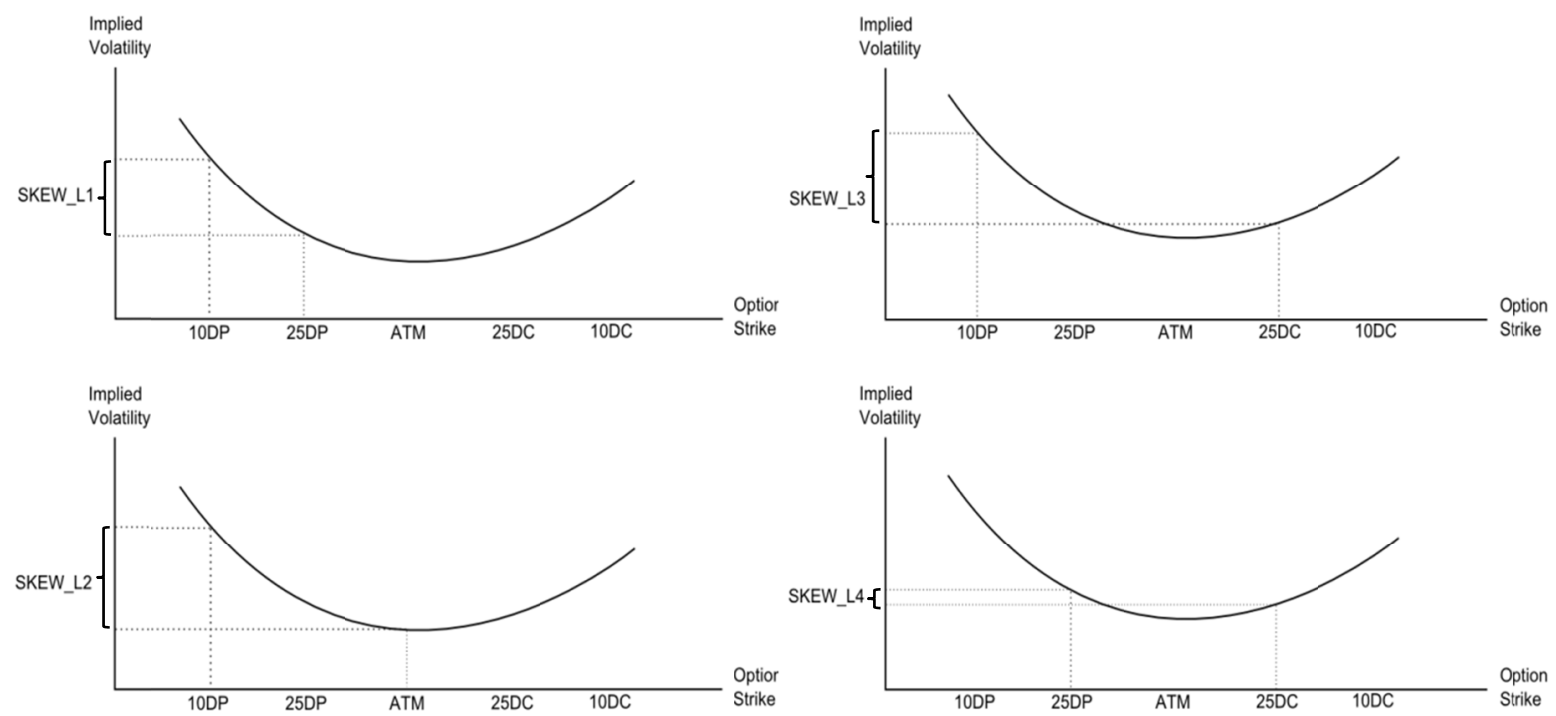

Figure 1. Skew definitions 1 to 4 illustrated

Now, I am ready to define the probit model central to this study:

where

$$
p_{t}=\operatorname{Pr}\left[y_{t}=1 \mid x_{t}\right]=\Phi\left[\beta_{1}+\beta_{2} \cdot A T M I V_{t}+\beta_{3} \cdot \text { Carry }_{t}+\beta_{4} \cdot \text { Skew }_{t}\right]
$$

$y_{t}$ : indicator function taking value 1 if a jump occurred between day $t$ and $(t+s)$; 
$A T M I V_{t}$ : at-the-money implied volatility at time $t$;

Carry $_{t}$ : 1-month forward premium at time $t$ (represents net carry of a currency pair);

Skew $_{t}$ : degree of left or right skew at time $t$.

The above probit regression assumes a monotonic (as opposed to quadratic or higher order) relationship between implied volatility skew and the probability of a price jump occurring within the time horizon $\mathrm{t}$ to $(t+s)$, which is consistent with methodology in existing empirical literature and the jump-diffusion framework.

The regression is performed for all combinations of four currency pairs, three distinct option time to maturities, two directions of jumps (up and down jumps with left and right skew measures respectively), five skew definitions and for absolute price jumps cum $\operatorname{GARCH}(1,1)$ normalised jumps as defined earlier. Note that Carry $y_{t}$ was excluded in the study in the initial exploratory stage - I report both results from across all currencies and

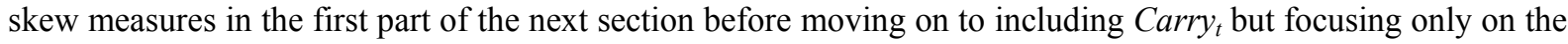
first skew measure for the sake of brevity. Finally, I calculate the marginal effects of the probit coefficients and comment on their values and significance.

\section{Results and Discussion}

Given that 60 probit regressions were performed for each of the four currencies, I divide the presentation of the results into the several sub-sections to aid clarity. Results are presented in Tables 1 to 10 in the following pages.

\subsection{At-the-Money Implied Volatility}

Before answering the research question as to whether there exists information in implied volatility (IV) skew that can help predict price jumps after abstracting from ATM IV, I first observe the significance of ATM IV in predicting, ex-ante, the probability of price jumps. It is seen from Table 1 that in the case of downward price jumps not normalising for $\operatorname{GARCH}(1,1)$ volatility (I shall refer to this simply as 'price jumps', and the GARCH(1,1) scaled price jumps as 'scaled price jumps'), ATM IV plays a significant role across all four currencies, all five skew measures and all three time periods. Further, the same significance is observed with upward price jumps as in Table 2. In both cases, all of the ATM IV coefficients are significant and positive in each and every probit regression, implying that an increase in ATM IV increases the probability of a price jump, both up and down, occurring within the option maturity time horizon. Such does not come at a surprise - high implied volatility driven by some combination of high realised volatility and market expectations of high volatility going forward naturally leads to more volatile price movements on a forward looking basis, especially given the heteroskedastic nature of financial time series of which a primary characteristic is the clustering of volatility.

Next, attention is turned to $\operatorname{GARCH}(1,1)$ scaled price jumps. Here, the magnitude of daily percentage price movements are scaled by the daily 2 -week $\operatorname{GARCH}(1,1)$ conditional volatility estimate in an attempt to control for realised volatility in the probit regression, as Doran, Peterson and Tarrant (2007) had done so in the 'LM jumps' segment of their paper but with an equally-weighted backward-looking window in their case. Given that ATM IV varies with - and is to some extent determined by - realised volatility, one can expect now that ATM IV becomes insignificant as a predictor of scaled price jumps. Such is what is observed in a large portion of the probit regressions results in Table 3 (scaled down jumps) and Table 4 (scaled up jumps) - approximately half of the time, the ATM IV coefficient is insignificant. It is also observed that in the majority of the regressions where ATM IV is significant, the ATM IV coefficient is in fact negative, implying that an increase in ATM IV actually decreases the probability of upward and downward price jumps. While determining the root cause of such a phenomenon is out of the scope of this paper, such could well be due to the options market systematically over-estimating the probability of price jumps in a regime of exceptionally high realised volatility, which in turn may be justified as rational by the fact that the options market is attempting to price in a more leptokurtic distribution of returns than what is typical and what is assumed when only the first two moments are used to represent a non-normal return distribution. 
Table 1. Probit regression coefficients, downward price jumps vs. ATM IV and Left IV skew

\begin{tabular}{|c|c|c|c|c|c|c|c|c|c|}
\hline & & \multicolumn{2}{|c|}{ EURUSD } & \multicolumn{2}{|c|}{ JPYUSD } & \multicolumn{2}{|c|}{ GBPUSD } & \multicolumn{2}{|c|}{ AUDUSD } \\
\hline & & ATM IV & Skew & ATM IV & Skew & ATM IV & Skew & ATM IV & Skew \\
\hline \multirow[t]{5}{*}{$2 w$} & Skew L1 & $0.2 * *$ & $0.51^{* *}$ & $0.15^{* *}$ & -0.01 & $0.17 * *$ & 0.18 & $0.15^{* *}$ & 0.05 \\
\hline & Skew L2 & $0.22 * *$ & $0.24 * *$ & $0.14 * *$ & 0.04 & $0.17 * *$ & 0.07 & $0.14 * *$ & 0.05 \\
\hline & Skew L3 & $0.23 * *$ & $0.15^{* *}$ & $0.13 * *$ & $0.05^{*}$ & $0.18 * *$ & 0.04 & $0.14 * *$ & 0.04 \\
\hline & Skew L4 & $0.24 * *$ & $0.2 * *$ & $0.11 * *$ & $0.13 * *$ & $0.18 * *$ & 0.04 & $0.14 * *$ & $0.07 *$ \\
\hline & Skew L5 & $0.25 * *$ & $2.94 * *$ & $0.13 * *$ & $2.21 * *$ & $0.19 * *$ & 0.12 & $0.15^{* *}$ & $1.61 *$ \\
\hline \multirow[t]{5}{*}{$1 \mathrm{~m}$} & Skew L1 & $0.28 * *$ & $0.59 * *$ & $0.17 * *$ & -0.06 & $0.22 * *$ & -0.09 & $0.16^{* *}$ & 0.03 \\
\hline & Skew L2 & $0.3 * *$ & $0.25^{* *}$ & $0.16^{* *}$ & 0 & $0.21 * *$ & -0.01 & $0.17 * *$ & 0 \\
\hline & Skew L3 & $0.32 * *$ & $0.15^{* *}$ & $0.14 * *$ & 0.03 & $0.21 * *$ & 0 & $0.17 * *$ & -0.01 \\
\hline & Skew L4 & $0.33 * *$ & $0.19 * *$ & $0.13 * *$ & $0.1 * *$ & $0.2 * *$ & 0.02 & $0.17 * *$ & -0.02 \\
\hline & Skew L5 & $0.34 * *$ & $2.42 * *$ & $0.13 * *$ & $2.3^{* *}$ & $0.2 * *$ & 0.29 & $0.17 * *$ & -0.51 \\
\hline \multirow[t]{5}{*}{$3 m$} & Skew L1 & $0.24 * *$ & $0.31 * *$ & $0.19 * *$ & $0.1 * *$ & $0.15 * *$ & $0.97 * *$ & $0.32 * *$ & $-0.46 * *$ \\
\hline & Skew L2 & $0.26 * *$ & $0.11^{* *}$ & $0.18^{* *}$ & $0.08 * *$ & $0.15 * *$ & $0.2 * *$ & $0.31 * *$ & $-0.24 * *$ \\
\hline & Skew L3 & $0.28 * *$ & $0.05^{*}$ & $0.17 * *$ & $0.09 * *$ & $0.17 * *$ & $0.13 * *$ & $0.31 * *$ & $-0.2 * *$ \\
\hline & Skew L4 & $0.29 * *$ & 0.04 & $0.16^{* *}$ & $0.19 * *$ & $0.18 * *$ & $0.18 * *$ & $0.29 * *$ & $-0.32 * *$ \\
\hline & Skew L5 & $0.29 * *$ & 0.31 & $0.18^{* *}$ & $2.57 * *$ & $0.2 * *$ & $1.24 * *$ & $0.26^{* *}$ & $-4.76 * *$ \\
\hline
\end{tabular}

Note. $2 \mathrm{w}, 1 \mathrm{~m}$ and $3 \mathrm{~m}$ refer to the 2 week, 1 month and 3 month option maturity time horizons respectively.

* significant at the $5 \%$ level, ** significant at the $1 \%$ level.

Table 2. Probit regression coefficients, upward price jumps vs. ATM IV and right IV skew

\begin{tabular}{|c|c|c|c|c|c|c|c|c|c|}
\hline & & \multicolumn{2}{|c|}{ EURUSD } & \multicolumn{2}{|c|}{ JPYUSD } & \multicolumn{2}{|c|}{ GBPUSD } & \multicolumn{2}{|c|}{ AUDUSD } \\
\hline & & ATM IV & Skew & ATM IV & Skew & ATM IV & Skew & ATM IV & Skew \\
\hline \multirow[t]{5}{*}{$2 w$} & Skew R1 & $0.2 * *$ & -0.18 & $0.16^{* *}$ & -0.06 & $0.2 * *$ & $0.41 *$ & $0.18 * *$ & $-0.49 * *$ \\
\hline & Skew R2 & $0.19 * *$ & -0.07 & $0.17 * *$ & 0.01 & $0.21 * *$ & $0.24 * *$ & $0.17 * *$ & $-0.22 * *$ \\
\hline & Skew R3 & $0.19^{* *}$ & -0.03 & $0.17^{* *}$ & 0.02 & $0.22 * *$ & $0.2^{* *}$ & $0.16^{* *}$ & $-0.11^{* *}$ \\
\hline & Skew R4 & $0.19 * *$ & -0.03 & $0.18 * *$ & 0.05 & $0.23 * *$ & $0.29 * *$ & $0.16^{* *}$ & $-0.12 * *$ \\
\hline & Skew R5 & $0.19 * *$ & -0.3 & $0.17 * *$ & 0.49 & $0.21 * *$ & $2.16^{* *}$ & $0.17 * *$ & $-2.61 * *$ \\
\hline \multirow[t]{5}{*}{$1 \mathrm{~m}$} & Skew R1 & $0.24 * *$ & -0.11 & $0.21 * *$ & -0.02 & $0.27 * *$ & -0.03 & $0.21 * *$ & $-0.73 * *$ \\
\hline & Skew R2 & $0.24 * *$ & -0.06 & $0.21 * *$ & 0 & $0.27 * *$ & 0.12 & $0.2 * *$ & $-0.34 * *$ \\
\hline & Skew R3 & $0.23^{* *}$ & -0.04 & $0.21 * *$ & -0.01 & $0.29 * *$ & $0.16^{* *}$ & $0.18^{* *}$ & $-0.19 * *$ \\
\hline & Skew R4 & $0.23 * *$ & -0.05 & $0.21 * *$ & -0.01 & $0.31 * *$ & $0.3 * *$ & $0.17 * *$ & $-0.24 * *$ \\
\hline & Skew R5 & $0.23 * *$ & $-0.99 *$ & $0.21 * *$ & 0.05 & $0.28 * *$ & $2.44 * *$ & $0.2 * *$ & $-4.52 * *$ \\
\hline \multirow[t]{5}{*}{$3 m$} & Skew R1 & $0.28 * *$ & -0.08 & $0.37 * *$ & $0.52 * *$ & $0.27 * *$ & $-0.89 * *$ & $0.17 * *$ & $-0.76^{* *}$ \\
\hline & Skew R2 & $0.27 * *$ & $-0.09 *$ & $0.35 * *$ & $0.1 * *$ & $0.24 * *$ & $-0.29 * *$ & $0.14 * *$ & $-0.36^{* *}$ \\
\hline & Skew R3 & $0.26^{* *}$ & $-0.08 * *$ & $0.34 * *$ & 0.03 & $0.23 * *$ & $-0.06^{* *}$ & $0.12 * *$ & $-0.2 * *$ \\
\hline & Skew R4 & $0.24 * *$ & $-0.15^{* *}$ & $0.33^{* *}$ & -0.03 & $0.25 * *$ & 0.04 & $0.11^{* *}$ & $-0.26 * *$ \\
\hline & Skew R5 & $0.23 * *$ & $-3.48 * *$ & $0.33 * *$ & $-0.06^{*}$ & $0.23 * *$ & -0.06 & $0.15 * *$ & $-3.48 * *$ \\
\hline
\end{tabular}

Note. $2 \mathrm{w}, 1 \mathrm{~m}$ and $3 \mathrm{~m}$ refer to the 2 week, 1 month and 3 month option maturity time horizons respectively.

* significant at the $5 \%$ level, ** significant at the $1 \%$ level.

Table 3. Probit regression coefficients, GARCH(1,1) scaled downward price jumps vs. ATM IV and Left IV Skew

\begin{tabular}{|c|c|c|c|c|c|c|c|c|c|}
\hline & & \multicolumn{2}{|c|}{ EURUSD } & \multicolumn{2}{|c|}{ JPYUSD } & \multicolumn{2}{|c|}{ GBPUSD } & \multicolumn{2}{|c|}{ AUDUSD } \\
\hline & & ATM IV & Skew & ATM IV & Skew & ATM IV & Skew & ATM IV & Skew \\
\hline \multirow[t]{5}{*}{$2 w$} & Skew L1 & $-0.05 * *$ & $0.53 * *$ & 0.02 & $-0.15^{* *}$ & 0.02 & $0.23 *$ & 0 & 0.06 \\
\hline & Skew L2 & $-0.04 * *$ & $0.31 * *$ & 0.00 & -0.01 & 0 & $0.22 * *$ & -0.02 & 0.05 \\
\hline & Skew L3 & $-0.03 * *$ & $0.22 * *$ & -0.02 & 0.03 & 0 & $0.19 * *$ & $-0.02 *$ & $0.06^{*}$ \\
\hline & Skew L4 & $-0.02 *$ & $0.32 * *$ & $-0.04 * *$ & $0.11 * *$ & 0.01 & $0.34 * *$ & $-0.03 * *$ & $0.15^{* *}$ \\
\hline & Skew L5 & -0.01 & $3.32 * *$ & $-0.02 *$ & $1.52 * *$ & $0.04 * *$ & $2.62 * *$ & $-0.01^{*}$ & $2.86^{* *}$ \\
\hline \multirow[t]{2}{*}{$1 \mathrm{~m}$} & Skew L1 & $-0.14 * *$ & $1.04 * *$ & 0.01 & $-0.21^{* *}$ & 0 & $0.32 * *$ & $-0.03 * *$ & 0.01 \\
\hline & Skew L2 & $-0.11 * *$ & $0.44 * *$ & -0.01 & $-0.07 * *$ & -0.01 & $0.24 * *$ & $-0.03 * *$ & 0.02 \\
\hline
\end{tabular}




\begin{tabular}{|c|c|c|c|c|c|c|c|c|c|}
\hline \multirow{8}{*}{$3 m$} & Skew L3 & $-0.08 * *$ & $0.27 * *$ & -0.02 & -0.02 & -0.01 & $0.2 * *$ & $-0.03 * *$ & 0.02 \\
\hline & Skew L4 & $-0.05 * *$ & $0.35^{* *}$ & $-0.04 * *$ & 0.03 & 0 & $0.34 * *$ & $-0.03 * *$ & 0.03 \\
\hline & Skew L5 & $-0.03 * *$ & $3.69^{* *}$ & $-0.05^{* *}$ & $0.99 * *$ & $0.03 * *$ & $2.28 * *$ & $-0.03 * *$ & 0.78 \\
\hline & Skew L1 & $-0.23 * *$ & $0.78^{* *}$ & $0.09 * *$ & $-0.35^{* *}$ & 0 & -0.07 & $-0.07 * *$ & -0.03 \\
\hline & Skew L2 & $-0.19 * *$ & $0.33^{* *}$ & $0.08 * *$ & $-0.19 * *$ & -0.02 & 0 & $-0.07 * *$ & 0.02 \\
\hline & Skew L3 & $-0.16^{* *}$ & $0.21 * *$ & $0.05^{* *}$ & $-0.11^{* *}$ & -0.02 & 0.01 & $-0.06 * *$ & -0.03 \\
\hline & Skew L4 & $-0.13 * *$ & $0.26^{* *}$ & 0.02 & $-0.13 * *$ & $-0.02 *$ & 0.05 & $-0.06 * *$ & $-0.06^{*}$ \\
\hline & Skew L5 & $-0.12 * *$ & $2.76^{* *}$ & $-0.03 * *$ & $-0.58^{*}$ & -0.01 & -0.24 & $-0.07 * *$ & -0.04 \\
\hline
\end{tabular}

Note. $2 \mathrm{w}, 1 \mathrm{~m}$ and $3 \mathrm{~m}$ refer to the 2 week, 1 month and 3 month option maturity time horizons respectively.

* significant at the $5 \%$ level, ** significant at the $1 \%$ level.

Table 4. Probit regression coefficients, GARCH(1,1) scaled upward price jumps vs. ATM IV and right IV skew

\begin{tabular}{|c|c|c|c|c|c|c|c|c|c|}
\hline & & \multicolumn{2}{|c|}{ EURUSD } & \multicolumn{2}{|c|}{ JPYUSD } & \multicolumn{2}{|c|}{ GBPUSD } & \multicolumn{2}{|c|}{ AUDUSD } \\
\hline & & ATM IV & Skew & ATM IV & Skew & ATM IV & Skew & ATM IV & Skew \\
\hline \multirow[t]{5}{*}{$2 w$} & Skew R1 & $0.03 * *$ & $-0.02 *$ & 0.01 & -0.09 & -0.01 & $-1.13 * *$ & 0 & $-0.72 * *$ \\
\hline & Skew R2 & $0.03 * *$ & -0.08 & $0.02 *$ & 0.04 & $0.03 * *$ & $-0.43 * *$ & $0.02 * *$ & $-0.31 * *$ \\
\hline & Skew R3 & $0.02 * *$ & $-0.06^{*}$ & $0.03 * *$ & $0.06^{*}$ & $-0.04 * *$ & $-0.21 * *$ & $-0.02 * *$ & $-0.18 * *$ \\
\hline & Skew R4 & $0.02 *$ & $-0.09 *$ & $0.05^{* *}$ & $0.12 * *$ & $-0.03 * *$ & $-0.17^{*}$ & $-0.03 * *$ & $-0.21 * *$ \\
\hline & Skew R5 & $0.02 * *$ & -0.56 & $0.03 * *$ & $1.65^{* *}$ & -0.01 & -0.59 & 0 & $-3.75^{* *}$ \\
\hline \multirow[t]{5}{*}{$1 \mathrm{~m}$} & Skew R1 & 0.01 & -0.02 & 0 & -0.07 & $-0.02 * *$ & $-0.82 * *$ & $-0.02 * *$ & $-0.53 * *$ \\
\hline & Skew R2 & 0.01 & $-0.07 *$ & 0.01 & 0.04 & $-0.04 * *$ & $-0.36 * *$ & $-0.03 * *$ & $-0.24 * *$ \\
\hline & Skew R3 & 0.01 & $-0.06^{* *}$ & $0.02 *$ & $0.05^{* *}$ & $-0.05 * *$ & $-0.19 * *$ & $-0.04 * *$ & $-0.15^{* *}$ \\
\hline & Skew R4 & 0 & $-0.13^{* *}$ & $0.04 * *$ & $0.1^{* *}$ & $-0.06^{* *}$ & $-0.2 * *$ & $-0.04 * *$ & $-0.19 * *$ \\
\hline & Skew R5 & 0 & $-1.38 * *$ & $0.02 * *$ & $1.61 * *$ & $-0.03 * *$ & -0.25 & $-0.02 * *$ & $-2.82 * *$ \\
\hline \multirow[t]{5}{*}{$3 \mathrm{~m}$} & Skew R1 & -0.02 & $-0.16^{* *}$ & $0.06^{* *}$ & $0.22 * *$ & $-0.05 * *$ & $-0.7 * *$ & $-0.06 * *$ & $-0.91 * *$ \\
\hline & Skew R2 & $-0.02 *$ & $-0.13 * *$ & $0.08 * *$ & $0.15^{* *}$ & $-0.08 * *$ & $-0.23 * *$ & $-0.09 * *$ & $-0.39 * *$ \\
\hline & Skew R3 & $-0.03 * *$ & $-0.1 * *$ & $0.1 * *$ & $0.11 * *$ & $-0.09 * *$ & $-0.07 *$ & $-0.11 * *$ & $-0.21 * *$ \\
\hline & Skew R4 & $-0.05 * *$ & $-0.18^{* *}$ & $0.11 * *$ & $0.15^{* *}$ & $-0.09 * *$ & -0.02 & $-0.12 * *$ & $-0.25^{* *}$ \\
\hline & Skew R5 & $-0.05 * *$ & $-2.58^{* *}$ & $0.07 * *$ & $1.93 * *$ & $-0.08 * *$ & $1.4 * *$ & $-0.08 * *$ & $-2.92 * *$ \\
\hline
\end{tabular}

Note. $2 \mathrm{w}, 1 \mathrm{~m}$ and $3 \mathrm{~m}$ refer to the 2 week, 1 month and 3 month option maturity time horizons respectively.

* significant at the $5 \%$ level, ** significant at the $1 \%$ level.

Table 5. Probit regression coefficients for EURUSD

\begin{tabular}{|c|c|c|c|c|c|c|c|c|c|}
\hline & & \multicolumn{2}{|c|}{ Absolute Down Jumps } & \multicolumn{2}{|c|}{ Absolute Up Jumps } & \multicolumn{2}{|c|}{ Scaled Down Jumps } & \multicolumn{2}{|c|}{ Scaled Up Jumps } \\
\hline & & ATM IV & Skew & ATM IV & Skew & ATM IV & Skew & ATM IV & Skew \\
\hline \multirow[t]{5}{*}{$2 \mathbf{w}$} & Skew L1 & $0.2 * *$ & $0.51 * *$ & $0.2 * *$ & -0.18 & $-0.05 * *$ & $0.53 * *$ & $0.03 * *$ & $-0.02 *$ \\
\hline & Skew L2 & $0.22 * *$ & $0.24 * *$ & $0.19 * *$ & -0.07 & $-0.04 * *$ & $0.31 * *$ & $0.03 * *$ & -0.08 \\
\hline & Skew L3 & $0.23 * *$ & $0.15^{* *}$ & $0.19 * *$ & -0.03 & $-0.03 * *$ & $0.22 * *$ & $0.02 * *$ & $-0.06^{*}$ \\
\hline & Skew L4 & $0.24 * *$ & $0.2 * *$ & $0.19 * *$ & -0.03 & $-0.02 *$ & $0.32 * *$ & $0.02 *$ & $-0.09 *$ \\
\hline & Skew L5 & $0.25^{* *}$ & $2.94 * *$ & $0.19 * *$ & -0.3 & -0.01 & $3.32 * *$ & $0.02 * *$ & -0.56 \\
\hline \multirow[t]{5}{*}{$1 \mathrm{~m}$} & Skew L1 & $0.28 * *$ & $0.59 * *$ & $0.24 * *$ & -0.11 & $-0.14 * *$ & $1.04 * *$ & 0.01 & -0.02 \\
\hline & Skew L2 & $0.3^{* *}$ & $0.25^{* *}$ & $0.24 * *$ & -0.06 & $-0.11 * *$ & $0.44 * *$ & 0.01 & $-0.07 *$ \\
\hline & Skew L3 & $0.32 * *$ & $0.15^{* *}$ & $0.23 * *$ & -0.04 & $-0.08 * *$ & $0.27 * *$ & 0.01 & $-0.06^{* *}$ \\
\hline & Skew L4 & $0.33 * *$ & $0.19 * *$ & $0.23 * *$ & -0.05 & $-0.05 * *$ & $0.35 * *$ & 0 & $-0.13 * *$ \\
\hline & Skew L5 & $0.34 * *$ & $2.42 * *$ & $0.23^{* *}$ & $-0.99 *$ & $-0.03 * *$ & $3.69 * *$ & 0 & $-1.38^{* *}$ \\
\hline \multirow[t]{5}{*}{$3 \mathrm{~m}$} & Skew L1 & $0.24 * *$ & $0.31 * *$ & $0.28 * *$ & -0.08 & $-0.23 * *$ & $0.78 * *$ & -0.02 & $-0.16^{* *}$ \\
\hline & Skew L2 & $0.26^{* *}$ & $0.11 * *$ & $0.27 * *$ & $-0.09^{*}$ & $-0.19 * *$ & $0.33 * *$ & $-0.02 *$ & $-0.13^{* *}$ \\
\hline & Skew L3 & $0.28 * *$ & $0.05^{*}$ & $0.26^{* *}$ & $-0.08 * *$ & $-0.16^{* *}$ & $0.21 * *$ & $-0.03 * *$ & $-0.1 * *$ \\
\hline & Skew L4 & $0.29 * *$ & 0.04 & $0.24 * *$ & $-0.15^{* *}$ & $-0.13 * *$ & $0.26^{* *}$ & $-0.05 * *$ & $-0.18^{* *}$ \\
\hline & Skew L5 & $0.29 * *$ & 0.31 & $0.23 * *$ & $-3.48^{* *}$ & $-0.12 * *$ & $2.76^{* *}$ & $-0.05 * *$ & $-2.58 * *$ \\
\hline
\end{tabular}

Note. $2 \mathrm{w}, 1 \mathrm{~m}$ and $3 \mathrm{~m}$ refer to the 2 week, 1 month and 3 month option maturity time horizons respectively.

* significant at the $5 \%$ level, ** significant at the $1 \%$ level. 
Table 6. Probit regression coefficients for JPYUSD

\begin{tabular}{|c|c|c|c|c|c|c|c|c|c|}
\hline & & \multicolumn{2}{|c|}{ Absolute Down Jumps } & \multicolumn{2}{|c|}{ Absolute Up Jumps } & \multicolumn{2}{|c|}{ Scaled Down Jumps } & \multicolumn{2}{|c|}{ Scaled Up Jumps } \\
\hline & & ATM IV & Skew & ATM IV & Skew & ATM IV & Skew & ATM IV & Skew \\
\hline \multirow[t]{5}{*}{$2 \mathbf{w}$} & Skew L1 & $0.15^{* *}$ & -0.01 & $0.16^{* *}$ & -0.06 & 0.02 & $-0.15^{* *}$ & 0.01 & -0.09 \\
\hline & Skew L2 & $0.14 * *$ & 0.04 & $0.17 * *$ & 0.01 & 0 & -0.01 & $0.02 *$ & 0.04 \\
\hline & Skew L3 & $0.13 * *$ & $0.05^{*}$ & $0.17 * *$ & 0.02 & -0.02 & 0.03 & $0.03 * *$ & $0.06^{*}$ \\
\hline & Skew L4 & $0.11^{* *}$ & $0.13^{* *}$ & $0.18^{* *}$ & 0.05 & $-0.04 * *$ & $0.11 * *$ & $0.05^{* *}$ & $0.12 * *$ \\
\hline & Skew L5 & $0.13 * *$ & $2.21 * *$ & $0.17 * *$ & 0.49 & $-0.02 *$ & $1.52 * *$ & $0.03 * *$ & $1.65^{* *}$ \\
\hline \multirow[t]{5}{*}{$1 \mathrm{~m}$} & Skew L1 & $0.17 * *$ & -0.06 & $0.21 * *$ & -0.02 & 0.01 & $-0.21 * *$ & 0 & -0.07 \\
\hline & Skew L2 & $0.16^{* *}$ & 0 & $0.21 * *$ & 0 & -0.01 & $-0.07 * *$ & 0.01 & 0.04 \\
\hline & Skew L3 & $0.14 * *$ & 0.03 & $0.21 * *$ & -0.01 & -0.02 & -0.02 & $0.02 *$ & $0.05^{* *}$ \\
\hline & Skew L4 & $0.13 * *$ & $0.1^{* *}$ & $0.21 * *$ & -0.01 & $-0.04 * *$ & 0.03 & $0.04 * *$ & $0.1 * *$ \\
\hline & Skew L5 & $0.13 * *$ & $2.3^{* *}$ & $0.21 * *$ & 0.05 & $-0.05 * *$ & $0.99 * *$ & $0.02 * *$ & $1.61^{* *}$ \\
\hline \multirow[t]{5}{*}{$3 \mathrm{~m}$} & Skew L1 & $0.19^{* *}$ & $0.1^{* *}$ & $0.37 * *$ & $0.52 * *$ & $0.09^{* *}$ & $-0.35^{* *}$ & $0.06^{* *}$ & $0.22 * *$ \\
\hline & Skew L2 & $0.18^{* *}$ & $0.08 * *$ & $0.35^{* *}$ & $0.1 * *$ & $0.08 * *$ & $-0.19 * *$ & $0.08 * *$ & $0.15^{* *}$ \\
\hline & Skew L3 & $0.17 * *$ & $0.09 * *$ & $0.34 * *$ & 0.03 & $0.05^{* *}$ & $-0.11 * *$ & $0.1 * *$ & $0.11 * *$ \\
\hline & Skew L4 & $0.16^{* *}$ & $0.19 * *$ & $0.33 * *$ & -0.03 & 0.02 & $-0.13^{* *}$ & $0.11 * *$ & $0.15^{* *}$ \\
\hline & Skew L5 & $0.18^{* *}$ & $2.57 * *$ & $0.33 * *$ & $-0.06^{*}$ & $-0.03 * *$ & $-0.58^{*}$ & $0.07 * *$ & $1.93 * *$ \\
\hline
\end{tabular}

Note. $2 \mathrm{w}, 1 \mathrm{~m}$ and $3 \mathrm{~m}$ refer to the 2 week, 1 month and 3 month option maturity time horizons respectively.

* significant at the $5 \%$ level, ** significant at the $1 \%$ level.

Table 7. Probit regression coefficients for GBPUSD

\begin{tabular}{|c|c|c|c|c|c|c|c|c|c|}
\hline & & \multicolumn{2}{|c|}{ Absolute Down Jumps } & \multicolumn{2}{|c|}{ Absolute Up Jumps } & \multicolumn{2}{|c|}{ Scaled Down Jumps } & \multicolumn{2}{|c|}{ Scaled Up Jumps } \\
\hline & & ATM IV & Skew & ATM IV & Skew & ATM IV & Skew & ATM IV & Skew \\
\hline \multirow[t]{5}{*}{$2 \mathbf{w}$} & Skew L1 & $0.17 * *$ & 0.18 & $0.2 * *$ & $0.41^{*}$ & 0.02 & $0.23^{*}$ & -0.01 & $-1.13^{* *}$ \\
\hline & Skew L2 & $0.17^{* *}$ & 0.07 & $0.21 * *$ & $0.24 * *$ & 0 & $0.22 * *$ & $0.03 * *$ & $-0.43^{* *}$ \\
\hline & Skew L3 & $0.18^{* *}$ & 0.04 & $0.22 * *$ & $0.2 * *$ & 0 & $0.19 * *$ & $-0.04 * *$ & $-0.21^{* *}$ \\
\hline & Skew L4 & $0.18^{* *}$ & 0.04 & $0.23 * *$ & $0.29 * *$ & 0.01 & $0.34 * *$ & $-0.03 * *$ & $-0.17 *$ \\
\hline & Skew L5 & $0.19 * *$ & 0.12 & $0.21 * *$ & $2.16^{* *}$ & $0.04 * *$ & $2.62 * *$ & -0.01 & -0.59 \\
\hline \multirow[t]{5}{*}{$1 \mathrm{~m}$} & Skew L1 & $0.22 * *$ & -0.09 & $0.27 * *$ & -0.03 & 0 & $0.32 * *$ & $-0.02 * *$ & $-0.82 * *$ \\
\hline & Skew L2 & $0.21 * *$ & -0.01 & $0.27 * *$ & 0.12 & -0.01 & $0.24 * *$ & $-0.04 * *$ & $-0.36^{* *}$ \\
\hline & Skew L3 & $0.21 * *$ & 0 & $0.29 * *$ & $0.16^{* *}$ & -0.01 & $0.2 * *$ & $-0.05^{* *}$ & $-0.19 * *$ \\
\hline & Skew L4 & $0.2 * *$ & 0.02 & $0.31 * *$ & $0.3 * *$ & 0 & $0.34 * *$ & $-0.06 * *$ & $-0.2 * *$ \\
\hline & Skew L5 & $0.2 * *$ & 0.29 & $0.28 * *$ & $2.44 * *$ & $0.03 * *$ & $2.28 * *$ & $-0.03 * *$ & -0.25 \\
\hline \multirow[t]{5}{*}{$3 m$} & Skew L1 & $0.15^{* *}$ & $0.97 * *$ & $0.27 * *$ & $-0.89 * *$ & 0 & -0.07 & $-0.05 * *$ & $-0.7 * *$ \\
\hline & Skew L2 & $0.15^{* *}$ & $0.2 * *$ & $0.24 * *$ & $-0.29 * *$ & -0.02 & 0 & $-0.08 * *$ & $-0.23 * *$ \\
\hline & Skew L3 & $0.17 * *$ & $0.13 * *$ & $0.23 * *$ & $-0.06^{* *}$ & -0.02 & 0.01 & $-0.09 * *$ & $-0.07 *$ \\
\hline & Skew L4 & $0.18^{* *}$ & $0.18^{* *}$ & $0.25 * *$ & 0.04 & $-0.02 *$ & 0.05 & $-0.09 * *$ & -0.02 \\
\hline & Skew L5 & $0.2 * *$ & $1.24 * *$ & $0.23 * *$ & -0.06 & -0.01 & -0.24 & $-0.08 * *$ & $1.4^{* *}$ \\
\hline
\end{tabular}

Note. $2 \mathrm{w}, 1 \mathrm{~m}$ and $3 \mathrm{~m}$ refer to the 2 week, 1 month and 3 month option maturity time horizons respectively.

* significant at the $5 \%$ level, ** significant at the $1 \%$ level.

Table 8. Probit regression coefficients for AUDUSD

\begin{tabular}{|c|c|c|c|c|c|c|c|c|c|}
\hline & & \multicolumn{2}{|c|}{ Absolute Down Jumps } & \multicolumn{2}{|c|}{ Absolute Up Jumps } & \multicolumn{2}{|c|}{ Scaled Down Jumps } & \multicolumn{2}{|c|}{ Scaled Up Jumps } \\
\hline & & ATM IV & Skew & ATM IV & Skew & ATM IV & Skew & ATM IV & Skew \\
\hline \multirow[t]{5}{*}{$2 w$} & Skew L1 & $0.15 * *$ & 0.05 & $0.18 * *$ & $-0.49 * *$ & 0 & 0.06 & 0 & $-0.72 * *$ \\
\hline & Skew L2 & $0.14^{* *}$ & 0.05 & $0.17 * *$ & $-0.22 * *$ & -0.02 & 0.05 & $0.02 * *$ & $-0.31 * *$ \\
\hline & Skew L3 & $0.14 * *$ & 0.04 & $0.16^{* *}$ & $-0.11 * *$ & $-0.02 *$ & $0.06^{*}$ & $-0.02 * *$ & $-0.18 * *$ \\
\hline & Skew L4 & $0.14 * *$ & $0.07 *$ & $0.16^{* *}$ & $-0.12 * *$ & $-0.03 * *$ & $0.15^{* *}$ & $-0.03 * *$ & $-0.21 * *$ \\
\hline & Skew L5 & $0.15^{* *}$ & $1.61 *$ & $0.17 * *$ & $-2.61 * *$ & $-0.01 *$ & $2.86^{* *}$ & 0 & $-3.75 * *$ \\
\hline \multirow[t]{3}{*}{$1 \mathrm{~m}$} & Skew L1 & $0.16^{* *}$ & 0.03 & $0.21 * *$ & $-0.73 * *$ & $-0.03 * *$ & 0.01 & $-0.02 * *$ & $-0.53 * *$ \\
\hline & Skew L2 & $0.17 * *$ & 0 & $0.2 * *$ & $-0.34 * *$ & $-0.03 * *$ & 0.02 & $-0.03 * *$ & $-0.24 * *$ \\
\hline & Skew L3 & $0.17 * *$ & -0.01 & $0.18^{* *}$ & $-0.19 * *$ & $-0.03 * *$ & 0.02 & $-0.04 * *$ & $-0.15^{* *}$ \\
\hline
\end{tabular}




\begin{tabular}{|c|c|c|c|c|c|c|c|c|c|}
\hline & Skew L4 & $0.17 * *$ & -0.02 & $0.17 * *$ & $-0.24 * *$ & $-0.03 * *$ & 0.03 & $-0.04 * *$ & $-0.19 * *$ \\
\hline & Skew L5 & $0.17 * *$ & -0.51 & $0.2 * *$ & $-4.52 * *$ & $-0.03 * *$ & 0.78 & $-0.02 * *$ & $-2.82 * *$ \\
\hline \multirow[t]{5}{*}{$3 \mathrm{~m}$} & Skew L1 & $0.32 * *$ & $-0.46^{* *}$ & $0.17 * *$ & $-0.76^{* *}$ & $-0.07 * *$ & -0.03 & $-0.06 * *$ & $-0.91 * *$ \\
\hline & Skew L2 & $0.31 * *$ & $-0.24 * *$ & $0.14 * *$ & $-0.36^{* *}$ & $-0.07 * *$ & 0.02 & $-0.09 * *$ & $-0.39 * *$ \\
\hline & Skew L3 & $0.31 * *$ & $-0.2 * *$ & $0.12 * *$ & $-0.2^{* *}$ & $-0.06^{* *}$ & -0.03 & $-0.11 * *$ & $-0.21 * *$ \\
\hline & Skew L4 & $0.29 * *$ & $-0.32 * *$ & $0.11 * *$ & $-0.26 * *$ & $-0.06^{* *}$ & $-0.06^{*}$ & $-0.12 * *$ & $-0.25 * *$ \\
\hline & Skew L5 & $0.26 * *$ & $4.76^{* * *}$ & $0.15 * *$ & $-3.48 * *$ & $-0.07 * *$ & -0.04 & $-0.08 * *$ & $-2.92 * *$ \\
\hline
\end{tabular}

Note. $2 \mathrm{w}, 1 \mathrm{~m}$ and $3 \mathrm{~m}$ refer to the 2 week, 1 month and 3 month option maturity time horizons respectively.

* significant at the $5 \%$ level, ** significant at the $1 \%$ level.

Table 9. Probit regression coefficients \& marginal effects (skew definition 1, downward price jumps)

\begin{tabular}{|c|c|c|c|c|c|c|}
\hline & $\begin{array}{l}\text { ATM IV } \\
\text { Coefficient }\end{array}$ & $\begin{array}{l}\text { 3M Fwd } \\
\text { Coefficient }\end{array}$ & $\begin{array}{l}\text { IV Skew } \\
\text { Coefficient }\end{array}$ & $\begin{array}{l}\text { ATM IV } \\
\text { SD * MEM } \\
\end{array}$ & $\begin{array}{l}1 M \text { Fwd * } \\
\text { SD * MEM }\end{array}$ & $\begin{array}{l}\text { Skew } \\
\text { SD * MEM }\end{array}$ \\
\hline \multicolumn{7}{|c|}{ EURUSD } \\
\hline 2 Week & $0.2 * *$ & $-0.0069 * *$ & $0.46^{* *}$ & $11.93 \%$ & $-3.69 \%$ & $3.54 \%$ \\
\hline 1 Month & $0.28 * *$ & $-0.0118^{* *}$ & $0.6^{* *}$ & $24.25 \%$ & $-9.49 \%$ & $8.10 \%$ \\
\hline 3 Month & $0.19 * *$ & $-0.0162 * *$ & $0.3^{* *}$ & $24.48 \%$ & $-20.55 \%$ & $8.08 \%$ \\
\hline \multicolumn{7}{|l|}{ JPYUSD } \\
\hline 2 Week & $0.2 * *$ & $-0.0042 * *$ & $-0.14 *$ & $18.93 \%$ & $-5.48 \%$ & $-3.11 \%$ \\
\hline 1 Month & $0.25 * *$ & $-0.0056^{* *}$ & $-0.24 * *$ & $32.67 \%$ & $-10.79 \%$ & $-9.77 \%$ \\
\hline 3 Month & $0.4^{* *}$ & $-0.01 * *$ & $-0.15^{* *}$ & $47.04 \%$ & $-21.43 \%$ & $-7.85 \%$ \\
\hline \multicolumn{7}{|c|}{ GBPUSD } \\
\hline 2 Week & $0.17 * *$ & $-0.0033^{* *}$ & 0.14 & $14.89 \%$ & $-2.66 \%$ & $1.62 \%$ \\
\hline 1 Month & $0.23 * *$ & $-0.0044 * *$ & -0.16 & $28.64 \%$ & $-5.25 \%$ & $-2.94 \%$ \\
\hline 3 Month & $0.16^{* *}$ & $-0.0048 * *$ & $0.33 * *$ & $23.00 \%$ & $-7.44 \%$ & $9.55 \%$ \\
\hline \multicolumn{7}{|c|}{ AUDUSD } \\
\hline 2 Week & $0.14 * *$ & $0.00299 *$ & 0.12 & $15.24 \%$ & $1.99 \%$ & $1.79 \%$ \\
\hline 1 Month & $0.15^{* *}$ & $0.004707 * *$ & $0.15^{*}$ & $24.34 \%$ & $4.87 \%$ & $3.92 \%$ \\
\hline 3 Month & $0.32 * *$ & $0.005081 * *$ & $-0.35^{* *}$ & $60.69 \%$ & $7.41 \%$ & $-17.27 \%$ \\
\hline
\end{tabular}

Note. $*$ significant at the $5 \%$ level, ** significant at the $1 \%$ level.

Table 10: Probit regression coefficients \& marginal effects (skew definition 1, upward price jumps)

\begin{tabular}{|c|c|c|c|c|c|c|}
\hline & $\begin{array}{l}\text { ATM IV } \\
\text { Coefficient }\end{array}$ & $\begin{array}{l}\text { 3M Fwd } \\
\text { Coefficient }\end{array}$ & $\begin{array}{l}\text { IV Skew } \\
\text { Coefficient }\end{array}$ & $\begin{array}{l}\text { ATM IV } \\
\text { SD * MEM }\end{array}$ & $\begin{array}{l}\text { 1M Fwd * } \\
\text { SD * MEM }\end{array}$ & $\begin{array}{l}\text { Skew } \\
\text { SD * MEM }\end{array}$ \\
\hline \multicolumn{7}{|c|}{ EURUSD } \\
\hline 2 Week & $0.19^{* *}$ & $-0.0031 * *$ & -0.16 & $17.02 \%$ & $-2.63 \%$ & $-1.30 \%$ \\
\hline 1 Month & $0.22 * *$ & $-0.0047 * *$ & -0.12 & $28.70 \%$ & $-5.63 \%$ & $-1.81 \%$ \\
\hline 3 Month & $0.21 * *$ & $-0.0142 * *$ & $-0.19 * *$ & $29.32 \%$ & $-19.93 \%$ & $-4.19 \%$ \\
\hline \multicolumn{7}{|l|}{ JPYUSD } \\
\hline 2 Week & $0.13 * *$ & $0.0055^{* *}$ & $-0.37 * *$ & $13.16 \%$ & $7.72 \%$ & $-4.81 \%$ \\
\hline 1 Month & $0.14 * *$ & $0.0068 * *$ & $-0.49 * *$ & $19.26 \%$ & $13.55 \%$ & $-8.73 \%$ \\
\hline 3 Month & $0.31 * *$ & $0.0032 * *$ & $0.26^{*}$ & $31.61 \%$ & $6.15 \%$ & $4.53 \%$ \\
\hline \multicolumn{7}{|c|}{ GBPUSD } \\
\hline 2 Week & $0.2 * *$ & $0.0068^{* *}$ & 0.28 & $15.59 \%$ & $4.99 \%$ & $1.14 \%$ \\
\hline 1 Month & $0.27 * *$ & $0.0054 * *$ & -0.02 & $29.27 \%$ & $5.80 \%$ & $-0.15 \%$ \\
\hline 3 Month & $0.27 * *$ & 0.0011 & $-0.86^{* *}$ & $38.81 \%$ & $1.66 \%$ & $-10.31 \%$ \\
\hline \multicolumn{7}{|c|}{ AUDUSD } \\
\hline 2 Week & $0.18^{* *}$ & 0.002162 & $-0.54 * *$ & $21.65 \%$ & $1.55 \%$ & $-3.74 \%$ \\
\hline 1 Month & $0.22 * *$ & $0.006526^{* *}$ & $-0.94 * *$ & $38.31 \%$ & $7.42 \%$ & $-12.49 \%$ \\
\hline 3 Month & $0.17 * *$ & $0.00207^{*}$ & $-0.83 * *$ & $33.16 \%$ & $3.02 \%$ & $-12.73 \%$ \\
\hline
\end{tabular}

Note. * significant at the $5 \%$ level, ** significant at the $1 \%$ level. 


\subsection{Implied Volatility Skew}

We now investigate whether there remains information in IV skew after abstracting from ATM IV across currencies, option maturities, up and down jumps, skew definitions and actual cum scaled price jumps.

\subsubsection{Downward Price Jumps}

Abstracting from ATM IV, I study the predictive power of IV skew in determining the probability of price jumps. It is first observed from Table 1 (downward price jumps) that the skew coefficient is significant and positive in most cases across all currencies, skew definitions and time horizons (with only the exception of AUDUSD on a 3 month maturity horizon). Such implies that an increase in IV skew corresponds to a higher probability of price jumps, and such a result, while novel to the foreign exchange asset class, corresponds to well-documented results in price jump literature covering the equity asset class. Later on, I include a proxy for currency carry-forward premium-in the probit regressions to see if such an empirical finding is robust to varying carry, with the rationale for such an investigation explained in Section 1.

\subsubsection{Upward Price Jumps}

Unlike within the equity space, currency implied volatility skew is much more 'flexible' in that in normal circumstances it may take on the form of a left or right volatility skew or a relatively symmetric volatility smile - such is opposed to the omnipresent leftward volatility skew that equity implied volatility is typical of. Naturally then, with currencies one would expect there to be information in the right skew as well in predicting upward currency price jumps. Such is the case as show in Table 2, where right IV skew is significant in a large proportion of the Probit regressions.

We note two important observations, however. First, it appears from Tables 1 and 2 that for EURUSD (the price of 1 EUR in USD) and JPYUSD, the significance and hence informational content in left skew is more often significant across skew definitions and time horizons than that of right skew. On the other hand, in the case of GBPUSD and AUDUSD, the significance of right skew dominates that of left skew. Such is more obvious when studying Tables 5, 6, 7 and 8 (which is the same information as in Tables 1 and 2 but re-ordered). It may hence be possible that a currency pair trades in a regime where either right or left skew dominates in informational content, although this may or may not preclude the possibility of both left and right skew being good predictors of price jump probability contemporaneously. Next, it is observed in Table 2 that a large proportion of skew coefficients relating to upward price jumps which are significant are also negative, implying counter-intuitively that a steeper right skew leads to a lower probability of upward price jumps. In both cases, determining if such is the case in general and finding the root causes of such phenomena is out of the scope of this paper. However, they stand as worthy objectives for future work.

\subsubsection{Option Time to Maturity}

In earlier studies covering the equity markets it was discovered that the informational content in IV skew attenuated with extending option maturity period. More specifically, Yan (2011) found that the profitability of a strategy based on the informational content in skew was mainly attributed to profits in the first of a six month holding period. Further, Doran, Peterson and Tarrant (2007) demonstrated the informational content of skew in a 10 to 30 day forward looking time horizon was absent in the 31 to 60 and 61 to 90 day maturity buckets. In this study, no such evidence is found - short maturity option IV skew appears from Tables 1,2,3 and 4 to be equally likely to be significant predictors of upward and downward price jumps.

\subsubsection{GARCH(1,1) Scaled Price Jumps}

For both upward and downward price jumps and across all currencies, using $\operatorname{GARCH}(1,1)$ scaled price jumps as opposed to percentage daily price changes did not seem to cause the significance of IV skew coefficients to occur less frequently. There hence remains informational content in IV skew after controlling for both ATM implied volatility and $\operatorname{GARCH}(1,1)$ conditional volatility, the latter of which is influenced by the evolution of realised volatility.

\subsection{Forward Premium Probit Model}

\subsubsection{Robustness of Probit Coefficients to Forward Premium}

Here, I am interested in examining whether the said predictive power of volatility skew is robust to currency carry. Towards that end, I employ a different approach typical of academic literature and of which is espoused in Menkhoff et al. (2012) - that being the segregation of a broad cross-section of currencies into low and high carry groups based on forward spread to spot. Instead, I recognise that currency carry differs not merely between currencies but also across time for a given currency, and I hence exploit such time variation by including carry as 
a factor in the probit regressions. The results of the analysis are presented in Table 9 (downward price jumps) and Table 10 (upward price jumps). For the sake of brevity, I only present results relating to upward and downward price jumps (not scaled by $\mathrm{GARCH}(1,1)$ conditional volatility) for all currencies based on the first measure of left and right skew defined in Section 2.

We see that the significance of forward premium is present in close to all of the regressions performed, proving that the time variation and cross sectional variation in currency forward premium - and hence carry - is a significant predictor of price jumps, both up and down, across the currencies studied and across option maturity horizons. Further, apart from carry, the significance of ATM IV is once again ubiquitous across all regressions and hence the informational content in ATM IV for predicting price jumps is robust to currency carry. More importantly, it is also observed that the significance of IV skew coefficients is also robust to currency carry. As such, it is seen that abstracting from the intuitive expectation that high interest rate 'carry currencies' will trade with equity-like characteristics given its high loading to the 'slope' factor as discussed in Section 1, the informational content of skew goes beyond such high carry currencies and remains significant even once carry is accounted for. Alas, therein lays my novel empirical result that adjusting for carry and ATM IV, there remains information in IV skew that is useful for predicting the probability of price jumps in an ex-ante manner.

\subsubsection{Marginal Effects Analysis}

Now, attention is focussed on the marginal effects of the mean (MEM) of ATM IV, 1-month forward premium and IV skew. To make the interpretation of the results more intuitive and meaningful, I present the MEM as the change in probability of a price jump occurring due to a one standard deviation increase in the coefficient under consideration. This is presented in the last 3 columns of Tables 9 and 10; to illustrate the interpretation of these results, the value of $11.93 \%$ in the first row and the third cell from the right indicates that, ceteris paribus, for a one standard deviation increase in ATM IV the probability of a downward price jump increases by $11.93 \%$. Cells in black are significant at the $5 \%$ level, while those in grey are not.

We see from both Tables 9 and 10 that while ATM IV plays the biggest role in influencing the probability of price jumps - based on the fact that the marginal effect of a one standard deviation increase in ATM IV is several fold larger than that of forward premium or IV skew - forward premium and IV skew both play an important and almost similarly sized role in determining the probability of price jumps.

\section{Conclusion}

In this study, I embarked on a novel investigation into whether option implied volatility and implied volatility skew contain information capable of elucidating, in an ex-ante manner, the probability of exceptional foreign exchange price movements. To this end, I performed 240 probit regressions involving four of the most widely traded currencies-the Euro, Pound Sterling, Australian Dollar and Japanese Yen-against the U.S. Dollar over varying option maturities, skew definitions and price jump definitions for both up and down jumps over the period 1 Jan 2007 to 18 November 2013. In addition to being the first paper in academic literature to apply such an analysis to the foreign exchange asset class, I further innovate by employing $\operatorname{GARCH}(1,1)$ conditional volatility estimates as a scaling factor in the alternative definition of price jumps. I also control the results for currency carry with 1-month forward premium serving as a proxy for carry.

We see unsurprisingly that the significance of at-the-money (ATM) implied volatility (IV) coefficients is ubiquitous in all the regressions based on unscaled price jumps, and that such significance is also present when price movements are scaled for $\operatorname{GARCH}(1,1)$ conditional volatility, though with less than absolute frequency. Such confirms the need to control for ATM IV in the analysis of skew. Doing so, I find as well that there contains information in IV skew that do help predict the probability of price jumps both before and after the price jumps are scaled by $\mathrm{GARCH}(1,1)$ conditional volatility. Interestingly, I also find that while both left and right skew influence the probability of price jumps, across currencies it appeared somewhat likely that only either left skew or right skew alone was significant in predicting price jumps, and not both contemporaneously. Equally surprising, as opposed to price jump literature covering the equity asset class, the informational content in skew in this study does not attenuate in any obvious fashion over the 2 week, 1 month and 3 month option maturity horizons considered. Finally, I find through robustness checks and probit marginal effects analysis that IV skew remains a significant predictor of price jumps even after controlling for currency carry, and that while ATM IV dominates in its ability to influence price jump probability, currency carry and IV skew both play a significant and equally sizeable role in their influence of price jump probability.

All in all, while more work is required to determine the underlying empirical and theoretical underpinnings of the results in this study, it has been demonstrated that foreign exchange IV skew, as in the well-documented field of equities, plays a significant role in determining the risk of exceptional price fluctuations. 


\section{References}

Ait-Sahalia, Y. (2004). Disentangling diffusion from jumps. Journal of Financial Economics, 74(3), 487-528. http://dx.doi.org/10.1016/j.jfineco.2003.09.005

Ait-Sahalia, Y., \& Jacod, J. (2008). Testing for jumps in a discretely observed process. Annals of Statistics, 37(1), 184-222. http://dx.doi.org/10.1214/07-AOS568

Ammann, M., Verhofen, M., \& Suss, S. (2009). Do Implied Volatilities Predict Stock Returns? Journal of Asset Management, 10(4), 222-234. http://dx.doi.org/10.1057/jam.2009.14

Bakshi, G., Kapadia, N., \& Madan, D. (2003). Stock return characteristics, skew laws, and differential pricing of individual equity options. Review of Financial Studies, 16(1), 101-143. http://dx.doi.org/10.1093/rfs/16.1.101

Bali, T., \& Hovakimian, A. (2009). Volatility Spreads and Expected Stock Returns. Management Science, 55(11), 1797-1812. http://dx.doi.org/10.1287/mnsc. 1090.1063

Ball, C. A., \& Roma, A. (1993). A Jump Diffusion Model for the European Monetary System. Journal of International Money and Finance, 12(5), 475-492. http://dx.doi.org/10.1016/0261-5606(93)90035-A

Ball, C. A., \& Torous, W. N. (1985). On jumps in common stock prices and their impact on call option pricing. Journal of Finance, 40(1), 155-173. http://dx.doi.org/10.2307/2328053

Banerjee, R., Doran, J., \& Peterson, D. (2006). Implied Volatility and Future Portfolio Returns. Journal of Banking and Finance, 31(10), 3183-3199. http://dx.doi.org/10.1016/j.jbankfin.2006.12.007

Bates, D. (1991). The crash of '87: Was it expected? The evidence from options markets. Journal of Finance, 46(3), 1009-1044. http://dx.doi.org/10.2307/2328552

Bates, D. (1996). Jumps and stochastic volatility: Exchange rate processes implicit in deutsche mark options. Review of Financial Studies, 9, 69-107. http://dx.doi.org/10.1093/rfs/9.1.69

Bates, D. (2000). Post-'87 crash fears in the S\&P500 futures options market. Journal of Econometrics, 94(1/2), 181-238. http://dx.doi.org/10.1016/S0304-4076(99)00021-4

Black, F., \& Scholes, M. (1973). The pricing of options and corporate liabilities. Journal of Political Economy, 81(3), 637-659. http://dx.doi.org/10.1086/260062

Bo, L., Wang, Y., \& Yang, X. (2010). Markov-Modulated Jump-Diffusions for Currency Option Pricing, $\begin{array}{llll}\text { Insurance. } \quad \text { Mathematics } & \text { 461-469. }\end{array}$ http://dx.doi.org/10.1016/j.insmatheco.2010.01.003

Bollen, N., \& Whaley, R. (2004). Does net buying pressure affect the shape of implied volatility functions? The Journal of Finance, 59(2), 711-753. http://dx.doi.org/10.1111/j.1540-6261.2004.00647.x

Bollerslev, T. (1986). Generalised Autoregressive Conditional Heteroskedasticity. Journal of Econometrics, 31(3), 307-327. http://dx.doi.org/10.1016/0304-4076(86)90063-1

Bollerslev, T., \& Zhou, H. (2006). Volatility puzzles: A unified framework for gauging return-volatility regressions. Journal of Econometrics, 131(1/2), 123-150. http://dx.doi.org/10.1016/j.jeconom.2005.01.006

Carhart, M. (1997). On Persistence in Mutual Fund Performance. Journal of Finance, 52(1), 57-82. http://dx.doi.org/10.1111/j.1540-6261.1997.tb03808.x

Chakravarty, S., Gulen, H., \& Mayhew, S. (2004). Informed trading in stock and option markets. Journal of Finance, 59(3), 1235-1257. http://dx.doi.org/10.1111/j.1540-6261.2004.00661.x

Cherian, J., \& Jarrow, R. (1998). Option markets, self-fulfilling prophecies, and implied volatilities. Review of Derivatives Research, 2(1), 5-37. http://dx.doi.org/10.1007/BF01487305

Chernov, M. (2007). On the role of risk premia in volatility forecasting. Journal of Business and Economic Statistics, 25, 411-426. http://dx.doi.org/10.1198/073500106000000350

Della Corte, P., Ramadorai, T., \& Sarno, L. (2013). Volatility Risk Premia and Exchange Rate Predictability. Working Paper, C.E.P.R. Discussion Papers, CEPR Discussion Papers: 9549.

Della Corte, P., Sarno, L., \& Tsiakas, I. (2011). Spot and Forward Volatility in Foreign Exchange. Journal of Financial Economics, 100(3), 496-513. http://dx.doi.org/10.1016/j.jfineco.2011.01.007

Dennis, P., \& Mayhew, S. (2002). Risk Neutral Skewness: Evidence from Stock Options. Journal of Financial and Quantitative Analysis, 37(3), 471-493. http://dx.doi.org/10.2307/3594989 
Diavatopoulos, D., Doran, J. S., \& Peterson, D. R. (2008). The information content in implied idiosyncratic volatility and the cross-section of stock returns: Evidence from the option markets. Journal of Futures Markets, 28(11), 1013-1039. http://dx.doi.org/10.1002/fut.20327

Doran, J. S., \& Krieger, K. (2010). Implications for asset returns in the implied volatility skew. Financial Analysis Journal, 66(1), 65-76. http://dx.doi.org/10.2469/faj.v66.n1.9

Doran, J. S., Peterson, D. R., \& Tarrant, B. C. (2007). Is there information in the volatility skew? The Journal of Futures Markets, 27(10), 921-959. http://dx.doi.org/10.1002/fut.20279

Eraker, B., Johannes, M., \& Polson, N. G. (2003). The impact of jumps in returns and volatility. Journal of Finance, 58(3), 1269-1300. http://dx.doi.org/10.1111/1540-6261.00566

Fama, E., \& French, K. (1993). Common Risk Factors in the Return on Stocks and Bonds. Journal of Financial Economics, 33(1). http://dx.doi.org/10.1016/0304-405X(93)90023-5

Foreign Exchange Turnover. (2013, April). Retrieved 18 Nov, 2013 from http://www.bis.org/publ/rpfx13fx.pdf

Gemmill, G. (1996). Did Option Traders Anticipate the Crash? Evidence From Volatility Smiles in the U.K. with U.S. Comparisons. Journal of Futures Markets, 16(8), 881-897. http://dx.doi.org/10.1002/(SICI)1096-9934(199612)16:8\%3C881::AID-FUT3\%3E3.3.CO;2-S

Giot, P. (2005). On the relationships between implied volatility indices and stock index returns. Journal of Portfolio Management, 31(3), 92-100. http://dx.doi.org/10.3905/jpm.2005.500363

Jegadeesh, N., \& Titman, S. (1993). Returns to Buying Winners and Selling Losers: Implications for Stock Market Efficiency. Journal of Finance, 48(1), 65-91. http://dx.doi.org/10.2307/2328882

Jiang, G. J., \& Tian, Y. S. (2005). The Model-Free Implied Volatility and Its Information Content. Review of Financial Studies, 18(4), 1305-1342. http://dx.doi.org/10.1093/rfs/hhi027

Jorion, P. (1989). On jump processes in the foreign exchange and stock markets. Review of Financial Studies, 1(4), 427-445. http://dx.doi.org/10.1093/rfs/hhi027

Lee, J., \& Kwon, T. (2006). The Information Content and Volatility Transfer Effect of Implied Volatility on KOSPI 200 Returns. The Korean Journal of Financial Engineering, 5(1), 41-59. Retrieved from http://wise.xmu.edu.cn/Master/News/NewsPic/200822615948282.pdf

Lee, S., \& Mykland, P. (2006). Jumps in real-time financial markets: A new nonparametric test and jump dynamics. Review of Financial Studies, 21(6), 2535-2563. http://dx.doi.org/10.2139/ssrn.891611

Lustig, H., Roussanov, N., \& Verdelhan, A. (2011). Common Risk Factors in Currency Markets. Review of Financial Studies, 24(11), 3731-3777. http://dx.doi.org/10.1093/rfs/hhr068

Maheu, J., \& McCurdy, T. (2007). Modelling foreign exchange rates with jumps. Frontiers of Economics and Globalization. http://dx.doi.org/10.1016/S1574-8715(07)00212-6

Menkhoff, L., Sarno, L., Schmeling, M., \& Schrimpf, A. (2012). Carry Trades and Global Foreign Exchange Volatility. Journal of Finance, 67(2), 681-718. http://dx.doi.org/10.1111/j.1540-6261.2012.01728.x

Merton, R. C. (1976). Option pricing when underlying stock returns are discontinuous. Journal of Financial Economics, 3(1/2), 125-144. http://dx.doi.org/10.1016/0304-405X(76)90022-2

Mixon, S. (2011). What Does Implied Volatility Skew Measure? Journal of Derivatives, 18(4), 9-25. http://dx.doi.org/10.3905/jod.2011.18.4.009

Pan, J. (2002). The jump-risk premia implicit in options: evidence from an integrated time-series study. Journal of Financial Economics, 63(1), 3-50. http://dx.doi.org/10.1016/S0304-405X(01)00088-5

Todorov, V. (2010). Variance Risk Premium Dynamics: The Role of Jumps. Review of Financial Studies, 23, 345-383. http://dx.doi.org/10.1093/rfs/hhp035

Xing, Y., Zhang, X., \& Zhao, R. (2010). What does the individual option volatility smirk tell us about future equity returns? Journal of Financial and Quantitative Analysis, 45(3), 641-662. http://dx.doi.org/10.1017/S0022109010000220

Yan, S. (2011). Jump Risk, Stock Returns, and Slope of Implied Volatility Smile. Journal of Financial Economics, 99(1), 216-233. http://dx.doi.org/10.1016/j.jfineco.2010.08.011 


\section{Copyrights}

Copyright for this article is retained by the author(s), with first publication rights granted to the journal.

This is an open-access article distributed under the terms and conditions of the Creative Commons Attribution license (http://creativecommons.org/licenses/by/3.0/). 